\title{
CHRIST AND CHILDREN. GRAPHIC INEDITA OF NORWID
}

\section{CHRIST AND CHILDREN IN THE TEMPLE OF JERUSALEM}

In 1894, a retrospective Exhibition of Polish Art was organized in Lviv in seven rooms of the Lviv Palace of Art. The exhibition presented a selection of works by Polish artists created between 1764 and 1886. Among more than 1400 exhibits, most numerous were drawings (598) and oil paintings (422), followed by watercolours, pastels and gouaches (219), and prints (179), supplemented with a modest collection of 21 sculptures. Jan Bołoz Antoniewicz wrote in the exhibition catalogue:

Polish art, as it is commonly known, has only risen to the global level in the last forty years; only in the second half of our century has it become an independent, separate element, generally known and recognised in the whole area of modern art. However, as Polish art has been growing in purely artistic and technical virtues, it has also reinforced its national-ideological content. Therefore, it is of substantial importance for the civilisation and the mental development of our nation, no lesser than our great poetry in the first half of our century. ${ }^{1}$

The time period of the exhibition was marked, on one hand, by the ascension to the throne by Stanisław August Poniatowski, "who undoubtedly laid the cornerstone for modern Polish art by bringing in eminent masters and by establishing the

${ }^{1}$ Katalog Ilustrowany Pierwszej Wielkiej Wystawy Sztuki Polskiej w Krakowie, Kraków 1887, p. IX. The exhibition was organised in Sukiennice as part of the National Agricultural, Industrial, Ethnographic and Polish Art Exhibition. Norwid's works were not exhibited, but it is worth noting that one of the exhibit was a portrait of the poet, painted by Pantaleon Szyndler. See ibid., p. 16, no. 232 . 
so-called Royal Painting House," and, on the other hand, "the first great exhibition of Polish art" organized in Kraków in $1887 .^{2}$

The Lviv exhibition included four drawings by Norwid: Chrystus stapajacy po falach jeziora [Christ Walking on the Waves of the Lake] (1852), belonging to Wawrzyniec Count Belzenstjern-Engeström from Poznań; La Confiance from Jerzy Kieszkowski's collection from Kraków; Chrystus przed kościołem [Christ in front of the Church] (1855), belonging to Ludwik Kastory from Wola Justowska; and Pompei (1855), owned by Ludwik Michałowski from Kraków. ${ }^{3}$ The selection of works was not of representative character; it seemed to be determined by practical reasons, depending on the possibility of obtaining the exhibits. Two drawings are now in the museum collection: La Confiance in the National Museum in Poznan, ${ }^{4}$ and Pompei in the National Museum in Kraków. As for the two biblical scenes - they are considered to be lost and the main source of knowledge about these items are the descriptions in the catalogue of said exhibition:

1085. Chrystus stapajacy po falach jeziora [Christ Walking on the Waves of the Lake]. On the right, the disciples, letting go of the net, are steering to the left: the figure of the Saviour walking on the water is approaching them. Label on the bottom right: "Cypryan Norwid invenit 1852." Drawing, pen on white paper, height $14 \mathrm{~cm}$, width $24.5 \mathrm{~cm}$. [...]

1087. Chrystus przed kościotem [Christ in front of the Church] [sic!]. The Saviour, having chased the stallholders out of the temple, is standing, greeted by the people, on the right side women and children are reaching out to him. (According to Matthew XXI, 15-17). Label: "composed and drawn according to the text by Cyprian Norwid 1855 in Paris." Drawing, sepia on paper, height $45 \mathrm{~cm}$, width $42 \mathrm{~cm}$. [... $]^{6}$

The themes taken from the New Testament occupy an important place in Norwid's iconography. Unlike the Old Testament, which is represented in Norwid's output only by few compositions, most of which are images of the heroes of biblical books; the evangelical scenes are filled with a considerable amount of cardboard and "karteczki i złamki" [slips and snippets], as the artist used to call

2 Ibid., p. X.

3 J. BoŁoz Antoniewicz, Katalog Ilustrowany Wystawy Sztuki Polskiej od roku 1764-1886, Lviv 1894, p. 235, items 1085-1088.

4 Three other drawings by Norwid from Kieszkowski's collection have also been submitted to the Museum: Wtaściciel kawiarni Caprice [The owner of Cafe Caprice], Dwaj kelnerzy z kawiarni Caprice [Two waiters from Cafe Caprice] and Szatan [Satan].

${ }^{5}$ In the following parts of the article, the drawing will be called: Chrystus i dzieci w światyni jerozolimskiej [Christ and children in the Temple of Jerusalem] (after: J.W. GoMULICKI, Tytutowy rejestr utworów Norwida w kolejności chronologicznej, PWsz XI, 230).

${ }^{6}$ J. Boloz Antoniewicz, Katalog Ilustrowany, p. 235. 
his smaller, more intimate sketches. Thus, together with Norwid, we can follow the life of Christ, starting with the scene where Mary and St. Joseph are seeking refuge in Bethlehem (the etching Nie było dla nich miejsca w gospodzie [There was no Room for Them in the Inn]), through the Saviour's childhood (the etching Św. Józef z Dzieciatkiem [St. Joseph with the Child], sketches with the Holy Family), events from His public activity (sketches depicting the Saviour's disputes with Pharisees and illustrating evangelical miracles, e.g. Wskrzeszenie Lazarza [The Resurrection of Lazarus], Chrystus i kobieta chananejska [Christ and the Canaanite Woman]) as well as representations of the Passion of Christ (e.g. the etching Pragne [I Thirst], several sketches illustrating the Saviour's meeting with Barabbas, two watercolours depicting Zdjęcie z krzyża [The Descent from the Cross], numerous sketches of the crucified Christ). ${ }^{7}$

The drawing in the catalogue of the Lviv exhibition entitled Chrystus stapajacy po falach jeziora (lost, unknown) refers to the event that followed the miracle of the multiplication of loaves of bread described by three Evangelists: Matthew, Mark and John (Matthew 14, 22-34; Mark 6, $45-53$ and John 6, 15-21). After dusk, the Apostles got onto a boat to cross the lake. When they were fighting stormy waters and opposing wind, they saw a figure walking on the water which seemed to them to be a spectre. As the figure approached the boat, they heard the words: "Take heart; it is I. Do not be afraid!" and then they recognised Christ. In the gospel according to St. Matthew, there was an additional thread - St. Peter went out of the boat and was walking on the water towards the Saviour, but after a while he got scared and started sinking, but then Jesus saved him from drowning.

The analysed drawing is not the only depiction of this topic by Norwid. The National Library stores an expressive pen sketch entitled Lódź apostolska na jeziorze Genezareth [The Apostolic Boat on the Lake of Gennesaret] (1856), showing an outline of a sailboat with the Apostles floating in rough waters, which Christ is approaching from the left; the boat emerges from the tangle of freely drawn lines. Another drawing, a watercolour, dedicated to "Karol Kucz for a memory" (1856, lost), generally corresponding to the outline of the description of the work displayed at the exhibition, was published in Volume F of Pisma zebrane [Collected Works]. ${ }^{8}$ On the back of the paining there was the author's annotation indicating that it was made according to the (unknown) composition drawn by Norwid on the ship Pacifique in

7 See: E. Chlebowska, „, Co byłeś smutny aż do śmierci, a miłujacy zawsze”- motywy pasyjne w plastyce Norwida, [in:] Kulturowy wymiar twórczości Norwida, eds. J. C. Moryc OFM, R. Zajączkowski, Lublin 2016, pp. 133-156.

${ }^{8}$ C. Norwid, Pisma zebrane, Vol. F, published by Z. Przesmycki, Warszawa-Kraków 1911 [recte 1946], following p. 336 (the volume was published with several sets of reproductions, therefore not every copy contains a reproduction of the analysed drawing). 
1854. ${ }^{9}$ Apart from the four mentioned drawings, the creator of Solo also made, perhaps by repeating the dominant composition scheme, an oil painting entitled $Ł o ́ d z ́$ apostolska na jeziorze Genezareth [The Apostolic Boat on the Lake of Gennesaret] (unknown) mentioned in [Autobiografia artystyczna] [Artistic Autobiography]. ${ }^{10}$ The list above is not only a manifestation of documentary meticulousness, but it also allows us to reflect on the themes and motifs which Norwid was repeatedly returning to in his artistic work. With the images of only two compositions on the discussed theme (and one rather general description of another work), it is impossible to analyse in detail the differences between the different variants, but it can be seen that Norwid used a similar compositional scheme in most of these productions, with Christ approaching the boat on the right side. Therefore, he did not change the general arrangement of the scene, but only reworked the individual elements, placing of the characters within the group and their silhouettes.

In the case of the second evangelical scene on display at the Lviv exhibition, which is the main focus of this study, we deal with a different situation since the theme has no analogy in Norwid's known legacy. The drawing refers to the exchange between Christ and the Pharisees:

But when the chief priests and the teachers of the law saw the wonderful things he did and the children shouting in the temple courts, "Hosanna to the Son of David," they were indignant. "Do you hear what these children are saying?" they asked him. "Yes," replied Jesus, "have you never read, ",From the lips of children and infants you, Lord, have called forth your praise?" (Matthew 21, 15-17, NIV)

It is not difficult to guess that this scene is sought in vain in the artistic canon of events illustrating the Saviour's life. The creators from various epochs and schools usually reached for the event preceding this scene, showing Christ, who, filled with fervour for God's house, chased out traders, bankers and even animals from the Jerusalem Temple. Nevertheless, Norwid undertook to illustrate the episode following the expulsion of the stallholders and Christ's healing of the blind and lame gathered in the temple. Since there were no traditional iconographic patterns, it would be difficult to identify the subject of this representation without indicating the biblical siglum to which the drawing refers. ${ }^{11}$

9 The information comes from Zenon Przesmycki's Archive with Norwid's manuscripts, from the collection of notes entitled Materiaty do twórczości malarskiej i rysowniczej Cypriana Norwida [Materials Referring to Paintings and Drawings by Cyprian Norwid] (BN, MS III 6330, c. 501 v., along with a reproduction of the drawing).

10 PWsz VI, 558.

${ }^{11}$ The source of this information was not indicated in the catalogue of the Lviv exhibition. This issue will be resolved in the further part of this text. 


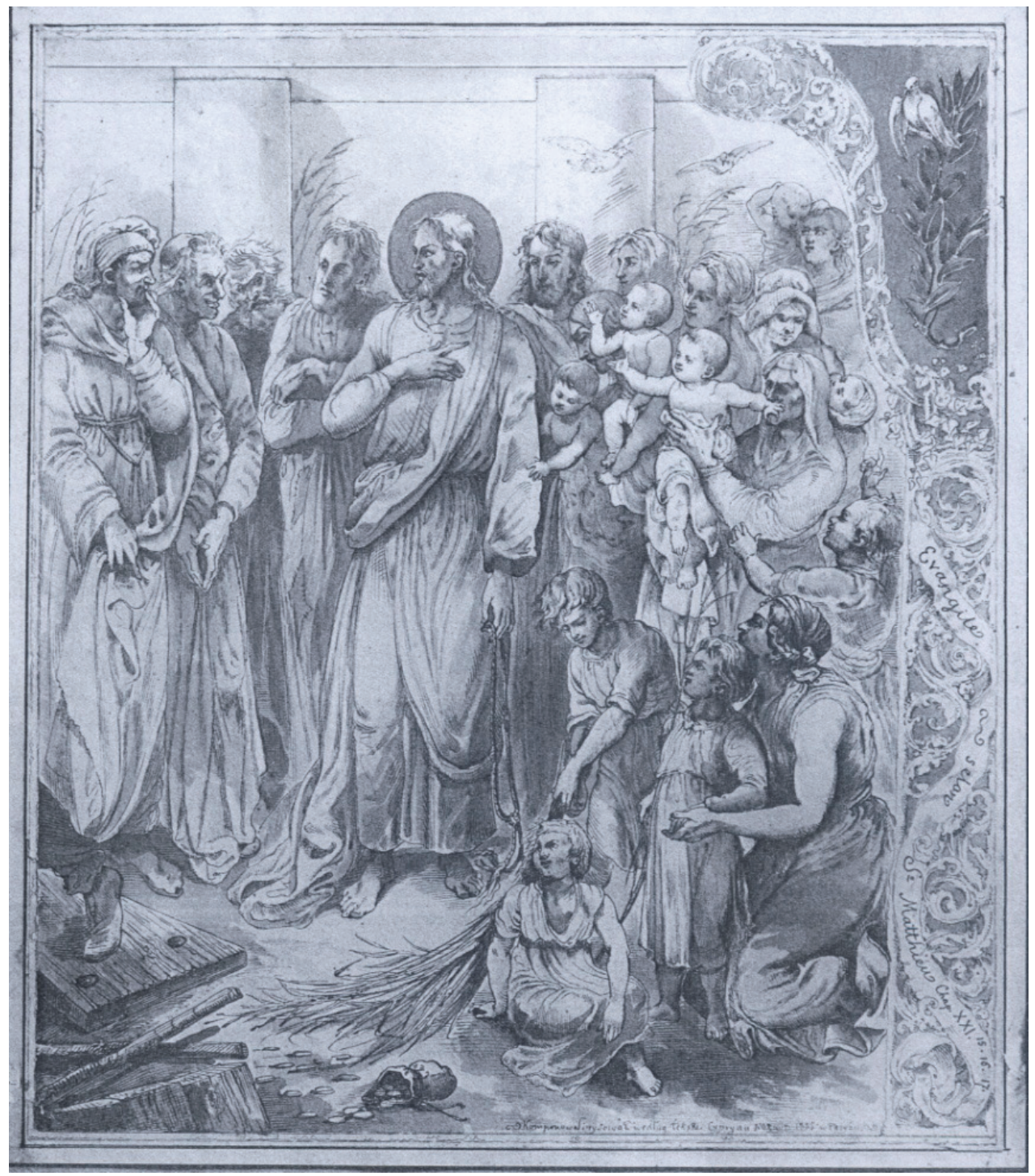

1. C. Norwid, Chrystus i dzieci ws światyni jerozolimskiej [Christ and Children in the Temple of Jerusalem], 1855 
The aforementioned catalogue description informs us about the considerable dimensions of this sepia and pen drawing $(45 \times 42 \mathrm{~cm})$ which undoubtedly distinguishes this work from small sketches that dominate the artist's legacy. Based on this sparing description, but still containing key information, it was possible to find a reproduction of the drawing in the form of a xerographic print preserved in Juliusz Wiktor Gomulicki's archive, deposited in the Manuscript Department of the Adam Mickiewicz Museum of Literature in Warsaw (il. 1). The copy was made based on a photograph of the drawing which was once in the collection of the editor of Pisma Wszystkie [Complete Works]. In December 2001, at an auction organised by Warsaw antiquarian bookshops Lamus, Gomulicki put up for sale two series of photographs. ${ }^{12}$ The first one included three photographs of Norwid's drawings from Marcelina Czartoryska's album, bearing the stamps of Ignacy Krieger's photography company based in Kraków. ${ }^{13}$ The second series consisted of 10 archival photographs of Norwid's plastic works from Kraków's public and private collections ${ }^{14}$. Among them there was also a photograph of the analysed drawing, $19.7 \times 11.2 \mathrm{~cm}$, described as follows: "Christ in the Temple of Jerusalem, already after the expulsion of the traders, surrounded by children and the blind and the lame, whom he was healing." ${ }^{.5}$ The photographs, glued on the identical thick grey cardboard pads (size $16 \times 25.2 \mathrm{~cm}$ ), did not bear company stamps or any other markings. Gomulicki suggested that they were made around 1912 by an undetermined Kraków-based photography company, as "an original supplement to the first volumes of Norwid's Pisma zebrane [Collected Works],

12 XII aukcja książek i grafiki. Warszawa 1 grudnia 2001, [LAMUS, Warsaw antiquarian bookshops, A. and H. Osełko], Warszawa 2001, pp. 92-93, items 354-366.

${ }^{13}$ Ibid., p. 91, items 354-356. Gomulicki suggested that the aforementioned series was originally intended to include a set of ten photographs, which, however, did not come to fruition and probably only three photographs, offered by the editor at the auction, were sold. I managed to establish that the collections of the Historical Museum of the City of Kraków include the archive of the Krieger company with ten glass negatives of Norwid's drawings from an album belonging to the duchess (MHK_811-K to MHK_820-K). See E. CHLEBowsKa, Na szklanych kliszach. Nieznane rysunki Norwida, czyli Album Marceliny Czartoryskiej, ,, Studia Norwidiana” 32(2014), pp. 147173.

${ }^{14}$ XII aukcja książek i grafiki, pp. 92-94, items 357-366.

${ }^{15}$ Ibidem, p. 93, item 360. On p. 92 there is Gomulicki's commentary on the whole photographic series. Other (preserved or lost) works by Norwid, presented in photographs include: Zoilus, Na ruinach Pompei [On the Ruins of Pompeii], Modlitwa dziecka [Child's Prayer], Chrystus na jednej ławie z Barabaszem [Christ on the Same Bench with Barabbas], Józefa Kuczyńska, Dwie mtode kobiety stojace naprzeciwko siebie i pragnace pochwycić fruwajacego między nimi motyla [Two Young Women Standing Opposite each other and Wishing to Catch a Butterfly Flying between Them], Męczennik [Martyr], Skrzypek niepotrzebny [The Useless Fiddler], Dialogue des Morts: Rembrandt-Phidias. 
compiled by Zenon Przesmycki." ${ }^{16}$ It follows from the circumstances above that the editor had no contact with the original drawing, and the photographic documentation made in the first decades of the $20^{\text {th }}$ century constitutes the last tangible trace of existence of the evangelical composition. The further history of this work by Norwid remains unknown, but it cannot be excluded that it could have been preserved in its original form. Therefore, one can still hope for its reappearance - maybe on the antiquarian market - in the future.

Despite the low interest in the discussed drawing, there are significant discrepancies in the literature concerning the title of the work. This, however, is not uncommon within Norwid Studies, as many of Norwid's artistic productions do not have uniform titles established by research and editorial tradition. The catalogue of the Lviv exhibition includes the title, Chrystus przed kościolem [Christ in front of the Church $],{ }^{17}$ which, for obvious reasons, needs to be corrected. Whereas J.W. Gomulicki - taking into account the drawing in the table presenting the list of Norwid's "artistic works" in chronological order, contained in Volume 11 of Pisma wszystkie [Complete Works] - used the title, Chrystus i dzieci w światyni jerozolimskiej [Christ and Children in the Temple of Jerusalem].${ }^{18}$ Gomulicki used yet another descriptive quasi-title in the description for the auction catalogue: "Chrystus w świątyni w Jerozolimie, już po wygnaniu z niej handlarzy, otoczony dziećmi oraz ślepymi i chromymi, których uzdrawiał" [Christ in the temple in Jerusalem, already after the expulsion of the traders, surrounded by children and the blind and the lame, whom he was healing]. The variability is largely due to the difficulty of putting the theme of the production into a title formula. In order to not complicate the situation, I decided to accept the title Chrystus i dzieci w światyni jerozolimskiej [Christ and Children in the Temple of Jerusalem], proposed by Gomulicki.

The copy of Norwid's photograph allows for an analysis of the visual layer of this composition, which makes it possible to go beyond the previous, quite general - because it is based solely on the iconographic key - placing of the drawing on

${ }^{16}$ Ibid., p. 92.

17 This title was used by J. Mycielski (Sto lat dziejów malarstwa w Polsce 1760-1860. Z okazji Wystawy retrospektywnej we Lwowie 1894 r. Kraków 1897, p. 629) and J. Polanowska in Norwid's biographical entry published in Stowniku Artystów Polskich i obcych w Polsce działajacych (zmartych przed 1966 r.). Malarze. Rzeźbiarze. Graficy (Vol. VI: N-Pc, eds. K. Mikocka-Rachubowa, M. Biernacka, Warszawa 1998, p. 140).

${ }^{18}$ PWsz XI, 230. In the most recent biography of the creator of Solo, the drawing was mistakenly presented as two independent items; one under the title taken from the catalogue, the other under the title given by Gomulicki (Z. Trojanowiczowa, Z. DAmbeK, J. Czarnomorska, Kalendarz życia i twórczości Cypriana Norwida, Vol. I: 1821-1860, Poznań 2007, p. 599). 
a map of Norwid's works. The scene shows Christ standing among the Apostles and the healed men by the wall of the Temple of Jerusalem, between two pious Jews (on the left) and a large group of women with children, gathering around the Saviour with great confidence (on the right). On the ground, we can see the remains of the tables being turned over and an abandoned purse of coins, while one of the children is laying a palm branch at the feet of Christ. The Saviour is facing the Pharisees whose faces, with their caricatured features, show a clear disapproval at the observed scene. The right margin of the composition is filled with a decorative bordure in the form of a stylised plant twig with a banderol bearing an inscription in French: "Évangile Selon So Matthiéu Chap. XXI. 15. 16. 17.," indicating a quotation that is the source of the scene. In the upper right corner, we see an oversized bay laurel branch with a white pigeon sitting on it. Along the lower edge of the drawing, Norwid wrote in small letters an expanded signature: "Composed and drawn according to the text by Cypryan Norwid $1855^{\circ}$ in Paris."

In the literature on the subject, the only analysis of the drawing can be found in Jerzy Mycielski who, on the pages of his history of painting in Poland, was extremely critical of Norwid's output stating that "he never knew what he wanted, both in rhyming and drawing, $[\ldots]$ he was some kind of immature Romantic in everything he did. ${ }^{19}$ Emphasising that he did not know the artistic legacy of Norwid, the scholar paid more attention to the drawings he had an opportunity to see at the Lviv exhibition stipulating that they still did not sufficiently reveal the character of Norwid as a plastic artist, who still remained a mystery. He considered only the sketch Pompei to be interesting, whereas he was critical of both evangelical scenes claiming that they are "in a genre style, rather than seriously religious, they resemble in some details, especially in those pale types from a far distance, the contemporary big church frescos by Flandrin, ${ }^{20}$ but ultimately, though interesting, they are weak and completely colourless., ${ }^{21}$

This illustration, despite all the details and careful execution, is certainly not a particularly successful drawing by Norwid. We can easily notice in this composition a lot of technical mistakes, characteristic of the creator of Solo, which are largely related to his lack of academic education - the characters are crowded together in a small space, the principles of perspective are ignored, and above all, there are compositional deficiencies that make the scene seem to be composed of two incompatible parts. On the left we see Christ and the Pharisees in static poses

19 J. Mycielski, Sto lat dziejów malarstwa w Polsce, p. 629.

${ }^{20}$ Jean-Hippolyte Flandrin (1809-1864) - a French painter who created under a strong influence of Nazarenism, the author of wall paintings in churches in Paris, Lyon and Nîmes as well as paintings on ancient and religious themes.

${ }^{21}$ J. Mycielski, Sto lat dziejów malarstwa w Polsce, p. 629. 
whose stiffness is only slightly broken by their gestures; perhaps this very part of the drawing evoked in Mycielski's mind an association with isocephalism of the processions painted by Flandrin. ${ }^{22}$ In turn, the group of women, who - if only because of a different scale of representation - are clearly separated from the first part, is characterised by a considerable variety of poses and gestures, and an unnatural crowding of figures that simply seem to burst the narrow space.

The remark concerning the splitting of the composition into two parts encourages the viewer to reflect again on the theme of the drawing and the methods of its representation. It is not difficult to notice that Norwid combined here two independent themes he undertook in his other productions - the Saviour's discussion with the Pharisees and Christ blessing children. The former is known from several works (mainly physiognomic studies) - two cursory sketches titled Chrystus w rozmowie z faryzeuszami [Christ in Conversation with the Pharisees] (BN, inv. no. R.708, R.710) and a larger composition Chrystus wśród faryzeuszy [Christ among the Pharisees] (BN, inv. no. R.573), which bears some analogies with the discussed drawing in terms of the collective scene layout. Until recently, the second theme has been known only from an interesting pen sketch from the collection of the National Library (inv. no. R.543). Interestingly, in this drawing, which was created about two decades later than the scene in the temple, we can see a repetition of one of the motifs used there - a child who is breaking free from the arms of his mother or nanny who is holding it, towards Christ, and is pushing with its hand away from her face. It is impossible to decide whether this child's gesture was reproduced by Norwid from nature, or taken from a foreign work; nonetheless, it was permanently inscribed by the artist in the scene of Christ's blessing. Also, the general arrangement of the group scene presented in the form of a dense, piled up group, refers to the earlier representation of this theme.

\section{CHRIST BLESSING CHILDREN}

Recently, the register of Norwid's artistic legacy has been supplemented with another previously unknown drawing illustrating the discussed topic. In October 2018, at an antiquarian auction organised by the Kraków-based Antykwariat Wójtowicza, the drawing Chrystus błogosławiacy dzieci [Christ Blessing Children $]^{23}$ (il. 2) was purchased for the collections of the National Library. The

${ }^{22}$ Cf. the painting frieze by Flandrin, surrounding the main nave and the chancel of the church of Saint-Vincent-de-Paul in Paris with a representation of 160 saints. See: https://www.patrimoinehistoire.fr/Patrimoine/Paris/Paris-Saint-Vincent-de-Paul.htm (accessed 30 January 2019).

${ }^{23}$ The auction took place on 13 October 2018 in the Polonia House in Kraków. See: M. 
drawing comes from the collection of Professor Kazimierz Wyka (1910-1975), an outstanding literary scholar and critic, Norwid Studies expert, the author of the classic monograph Cyprian Norwid. Poeta i sztukmistrz (Kraków 1948) and many interesting studies on the legacy of the author of Promethidion ${ }^{24}$ The drawing (size $22.4 \times 30.5 \mathrm{~cm}$ ), pen and ink, washed with white paint in selected parts of the figures and the background, on dark brown paper, with all of its surface glued on the cardboard (size $24.4 \times 32 \mathrm{~cm}$ ). Unfortunately, due to small differences in colour between the ink and the paper, it is difficult to notice, and even more so, to reproduce the details of this extremely meticulous drawing covered with a grid of subtle hatching which brings out a chiaroscuro pattern. On the right side, we can see Christ sitting and blessing the woman who is kneeling in front of Him with a girl. On the left, a second woman is approaching the Saviour with a baby in her arms, accompanied by two older children. Two Apostles are standing beside Christ: one is turning to Him and the other is leaning towards the walking child. At the right edge of the middle of the composition, there is a signature with the date written in pen: "C. NORWID / 1857 faciebat." The drawing from Kraków was based on a different compositional pattern than the previously discussed images of Christ's blessing. Norwid resigned here from reproducing a crowded scene in favour of a smaller group of several people, which emphasised the intimate, emotional dimension of the meeting with the Saviour. It would be difficult to point to a specific evangelical quotation that is the source of this representation, since the blessing of children is mentioned by most Evangelists (cf. Matthew 19, 13-15; Mark 10, 13-16; and Luke 18, 15-17).

It seems worthwhile to analyse more carefully the relations between the participants of this scene which manifests the artist's ability to build a lyrical mood that corresponds to the theme of the production. Christ is leaning with attention and care towards the kneeling woman, with one hand shaking her hand and with the other hovering over her head in a gesture of blessing. One of the Apostles (perhaps St. Peter) is gently holding the chin of the child, making eye contact with it. The group consisting of a mother and her three children is also greatly interesting and, at the same time, naturally charming. The infant is sitting calmly in its mother's arms and one of the children walking next to her, still maintaining close physical contact with the mother (cuddled to her leg), is leaning forward with a hint of uncertainty but also with curiosity. It is carefully observing the others,

Wójtowicz, P. Wójtowicz, 47 Aukcja. Antykwariat Wójtowicz, Kraków 2018, p. 99, item 226, Table 1. The drawing was purchased by the National Library at the asking price of PLN 48.000 (BN inv. no. R.22050/I).

24 The articles by Wyka devoted to the poet's work were collected in the book: K. WYKA, Cyprian Norwid: studia, artykuły, recenzje, Kraków 1989. 

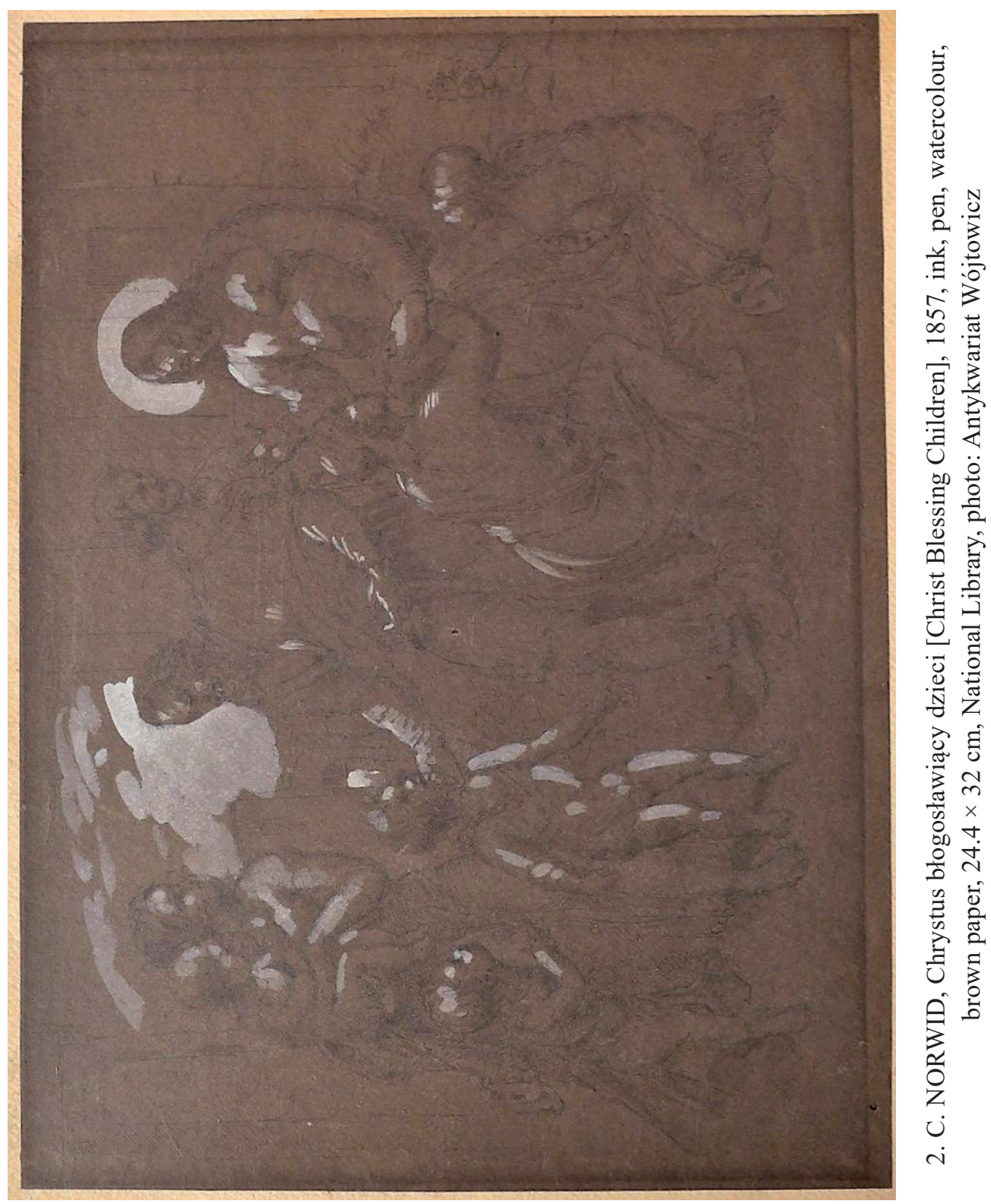
especially the Apostle leaning towards the third child at the front of the group. The network of sensitive gestures and gazes, which are an expression of the close bonds that saturate this intimate scene, allows us to see in this drawing an example of a successful representation of the theme that seems to have been important for the artist and encouraged him to search for appropriate means of expression. It is impossible not to mention here the significance of the theme of maternal love in Norwid's work, and more broadly of the woman-child relationship, which has been particularly emphasised in the examined scene.

Many years ago, Jerzy Sienkiewicz, who juxtaposed Norwid's work with Teofil Kwiatkowski's artistic legacy, drew attention to the extraordinary subtlety and poignant representation of females. This was later taken up by A. MelbechowskaLuty in her research. ${ }^{25}$ Illustrations depicting Christ surrounded by women and children are an eloquent testimony to the vitality of the analysed motifs which in Norwid's drawings are not limited only to genre scenes, but also readily include religious themes.

\section{ILLUSTRATIONS}

1. C. Norwid, Chrystus i dzieci w światyni jerozolimskiej, 1855, sepia, pen, $45 \times 42 \mathrm{~cm}$, lost drawing, a photo based on to the photocopy in the archives of J.W. Gomulicki at the A. Mickiewicz Museum of Literature in Warsaw.

2. C. NoRwID, Chrystus błogosławiacy dzieci, 1857, ink, pen, watercolour, brown paper, $24.4 \times 32 \mathrm{~cm}$, National Library, photo: Antykwariat Wójtowicz.

\section{REFERENCES}

XII aukcja ksiązek i grafiki. Warszawa 1 grudnia 2001, [LAMUS, Warsaw antiquarian bookshps, A. i H. Osełko], Warszawa 2001.

BoŁoz Antoniewicz J., Katalog Ilustrowany Wystawy Sztuki Polskiej od roku 1764-1886, Lwów 1894.

ChlebowsKa E., Norwid sztukmistrz nieznany, Lublin 2013.

Chlebowska E., Na szklanych kliszach. Nieznane rysunki Norwida, czyli Album Marceliny Czartoryskiej, „Studia Norwidiana” 32(2014), pp. 147-173.

25 J. Sienkiewicz, Norwid malarz, [in:] Pamięci Cypriana Norwida, Warszawa 1946, pp. 72-73; A. MelBeChowsKA-Luty, Teofil Kwiatkowski 1809-1891, Wrocław-Warszawa-Kraków 1966, pp. 60, 61, 86, 88, 121; see also E. ChlebowsKa, Norwid sztukmistrz nieznany, Lublin 2013, pp. 265-267. 
Chlebowska E., „Co byteś smutny aż do śmierci, a miłujacy zawsze”- motywy pasyjne w plastyce Norwida, [in:] Kulturowy wymiar twórczości Norwida, ed. J.C. Moryc OFM, R. Zajączkowski, Lublin 2016, pp. 133-156.

Gomulicki J.W., Tytułowy rejestr utworów Norwida w kolejności chronologicznej, PWsz XI, 226-233.

Katalog Ilustrowany Pierwszej Wielkiej Wystawy Sztuki Polskiej w Krakowie, Kraków 1887.

MelbechowsKa-Luty A., Teofil Kwiatkowski 1809-1891, Wrocław-Warszawa-Kraków 1966.

Mycielski J., Sto lat dziejów malarstwa w Polsce 1760-1860. Z okazji Wystawy retrospektywnej we Lwowie 1894 r., Kraków 1897.

Polanowska J., Cyprian Norwid, [in:] Stownik Artystów Polskich i obcych w Polsce działajacych (zmarlych przed 1966 r.). Malarze. Rzeźbiarze. Graficy (Vol. VI: N-Pc, eds. K. Mikocka-Rachubowa, M. Biernacka, Warszawa 1998, pp. 135-150.

Sienkiewicz J., Norwid malarz, [in:] Pamięci Cypriana Norwida, Warszawa 1946, pp. 61-77.

Trojanowiczowa Z., Dambek Z., Czarnomorska J., Kalendarz życia i twórczości Cypriana Norwida, Vol. I: 1821-1860, Poznań 2007.

Wójtowicz M., WóJtowicz P., 47 Aukcja. Antykwariat Wójtowicz, Kraków 2018.

Wyка K., Cyprian Norwid: studia, artykuty, recenzje, Kraków 1989.

\title{
CHRIST AND CHILDREN. \\ GRAPHIC INEDITA OF NORWID
}

\author{
$\mathrm{S} \mathrm{u} \mathrm{m} \mathrm{m} \mathrm{a} \mathrm{r} \mathrm{y}$
}

The aim of the article is to present two previously unknown drawings by Norwid, inspired by the New Testament, which have recently been added to the register of his artistic legacy. The first of the sketches Chrystus i dzieci w światyni jerozolimskiej [Christ and Children in the Temple of Jerusalem (1855, lost) illustrates a quotation from the Gospel of Matthew (Matthew 21, 15-17). The second composition Chrystus błogosławiacy dzieci [Christ Blessing Children] (1857, National Library) refers to an episode mentioned several times in the Gospels (Matthew 19, 13-15; Mark 10, 13-16; Lucas 18, 15-17).

Key words: Cyprian Norwid; Christian iconography; Jesus Christ; $19^{\text {th }}$-century Polish drawing; the Bible.

Translated by Rafat Augustyn

Edyta Chlebowska - PhD, art historian, employed at the Centre for the Study of Cyprian Norwid's Literature and Art, Catholic University of Lublin; e-mail: edytowo@gmail.com 